\title{
Hierarchic species-area relationships and the management of forest habitat islands in intensive farmland
}

\author{
Angela Lomba a,b,c,*, Ana Sofia Vaz ${ }^{\text {a,d }}$, Francisco Moreira ${ }^{\mathrm{e}}$, João Pradinho Honrado ${ }^{\mathrm{a}, \mathrm{d}}$ \\ ${ }^{a}$ Centro de Investigação em Biodiversidade e Recursos Genéticos (CIBIO), Edifício FC4, sala 1A, Rua do Campo Alegre, S/N, PT-4169-007 Porto, Portugal \\ ${ }^{\mathrm{b}}$ Alterra Wageningen University and Research Centre, NL-6708 Wageningen, The Netherlands \\ ${ }^{\mathrm{c}}$ Départment d'Ecologie et d'Evolution (DEE), Université de Lausanne, Bâtiment de Biologie, CH-1015 Lausanne, Switzerland \\ ${ }^{\mathrm{d}}$ Faculdade de Ciências da Universidade do Porto, Departamento de Biologia, Edifício FC4, sala 1A, Rua do Campo Alegre, S/N, PT-4169-007 Porto, Portugal

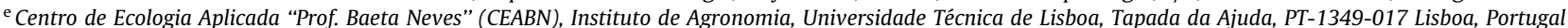

\section{A R T I C L E I N F O}

\section{Article history:}

Received 22 August 2012

Received in revised form 6 November 2012

Accepted 9 November 2012

Available online 5 January 2013

\section{Keywords:}

Dairy farmlands

Exotic plantations

Habitat fragmentation

Plant diversity

Semi-natural forests

Species-area relationship (SARs)

\section{A B S T R A C T}

Habitat loss and fragmentation due to land use changes are major threats to biodiversity in forest ecosystems, and they are expected to have important impacts on many taxa and at various spatial scales.

Species richness and area relationships (SARs) have been used to assess species diversity patterns and drivers, and thereby in the establishment of conservation and management strategies. Here we propose a hierarchical approach to achieve deeper insights on SARs in small forest islets in intensive farmland and to address the impacts of decreasing naturalness on such relationships.

In the intensive dairy landscapes of Northwest Portugal, where small forest stands (dominated by pines, eucalypts or both) represent semi-natural habitat islands, 50 small forest stands were selected and surveyed for vascular plant diversity. A hierarchical analytical framework was devised to determine species richness and inter- and intra-patch SARs for the whole set of forest patches (general patterns) and for each type of forest (specific patterns). Differences in SARs for distinct groups were also tested by considering subsets of species (native, alien, woody, and herbaceous).

Overall, values for species richness were confirmed to be different between forest patches exhibiting different levels of naturalness. Whereas higher values of plant diversity were found in pine stands, higher values for alien species were observed in eucalypt stands. Total area of forest (inter-patch SAR) was found not to have a significant impact on species richness for any of the targeted groups of species. However, significant intra-patch SARs were obtained for all groups of species and forest types.

A hierarchical approach was successfully applied to scrutinise SARs along a gradient of forest naturalness in intensively managed landscapes. Dominant canopy tree and management intensity were found to reflect differently on distinct species groups as well as to compensate for increasing stand area, buffering SARs among patches, but not within patches. Thus, the maintenance of small semi-natural patches dominated by pines, under extensive practices of forest management, will promote native plant diversity while at the same time contributing to limit the expansion of problematic alien invasive species.

(c) 2012 Elsevier B.V. All rights reserved.

\section{Introduction}

Forests have been acknowledged worldwide as essential providers of valuable ecosystem services, from habitat for biodiversity to provision of economic goods (Magura et al., 2008; Proença et al., 2010). The provision of such services is known to be dependent of the high diversity of living organisms inhabiting forest ecosystems (Benayas et al., 2008; Proença et al., 2010). Even so, biodiversity is declining at rapid rates, with the loss of habitat through land-use

\footnotetext{
* Corresponding author at: Centro de Investigação em Biodiversidade e Recursos Genéticos (CIBIO), Edifício FC4, sala 1A, Rua do Campo Alegre, S/N, PT-4169-007 Porto, Portugal. Tel.: +351 220402790; fax: +351 2204027098 .

E-mail address: angelalomba@fc.up.pt (A. Lomba).
}

change, the expansion of alien species, direct exploitation e.g. through hunting and trade, climate change, and pollution identified as major causes (Sala et al., 2000; Trisorio et al., 2010).

Distinct scales of influence have been related to the drivers of change in forest biodiversity patterns, with climate driving changes over large areas (Laughlin et al., 2011), human activities impacting on diversity patterns in intensively managed regions, and land-use and landscape heterogeneity influencing those patterns in local, finer grained contexts (Cayuela et al., 2006). Forest ecosystems have particularly been under the threat of land-use conversion and landscape fragmentation (Bengtsson et al., 2000; Guirado et al., 2007; Trisorio et al., 2010). Effects of habitat fragmentation have been documented for many taxa and at various spatial scales (e.g. Golden and Crist, 1999; Ewers and Didham, 
2006; Gonzalez et al., 2010; Trisorio et al., 2010; Rodríguez-Loinaz et al., 2012). Habitat fragmentation implies not only the pure loss of habitat, but also the reduction in size of the remnant habitat patches and their increasing spatial isolation, and it has been recognised as one of the most important threats to biodiversity, due to its effects on population viability, dispersal, and long-term persistence of species (Ewers and Didham, 2006; Gonzalez et al., 2010; Trisorio et al., 2010; Jamoneau et al., 2011).

Shifts in the way forests have been managed have been related to a decrease in the colonisation ability of plant species in isolated habitat fragments (Godefroid and Koedam, 2003b). Since many forests are intensively managed (Bengtsson et al., 2000; Godefroid and Koedam, 2003b; Proença et al., 2010) and, to a large extent, have been transformed into mono-cultural plantations of exotic species (Magura et al., 2008), a decrease of species richness and structural diversity in forest habitats has been observed (e.g. see Godefroid and Koedam, 2003a; Proença et al., 2010; Lomba et al., 2011).

The analysis of species richness and area relationships (SARs) has been stressed as a promising tool for the assessment of species diversity patterns (Tjørve, 2009, 2012). Highly applicable in the establishment of biodiversity conservation priorities and management programs (e.g. see Lawesson et al., 1998; Wang et al., 2011), SARs seem to be especially useful in the case of highly fragmented and disturbed landscapes where many smaller and few larger landscape units are characteristic (Lawesson et al., 1998; Pereira and Daily, 2006). In such context, in order to understand the capacity of habitats to conserve species diversity, many studies have used SARs to evaluate the effect of patch size on species richness in habitat fragments (Honnay et al., 1999; Godefroid and Koedam, 2003b; Gonzalez et al., 2010). Whilst the role of area in species conservation still remains controversial (e.g. see Godefroid and Koedam, 2003a), the benefit of having a number of smaller areas for conservation of plant species has been an accepted rule (Godefroid and Koedam, 2003b). In such context, relations between plant diversity in isolated patches and patch area (e.g. Zschokke et al., 2000) have been addressed, and different relationships have been observed for distinct species groups, including birds (Magura et al., 2008), plants (Kiviniemi and Eriksson, 2002; Rodríguez-Loinaz et al., 2012), woodland plant species and ancient forest species (Godefroid and Koedam, 2003b). The complementarity among species strategies (life forms; Morgan et al., 2011), their biogeographic history (Turner and Tjørve, 2005), habitat heterogeneity (e.g. related to urbanisation; Godefroid and Koedam, 2003b), origin and management (habitat diversity; Lawesson et al., 1998) have been referred as possible determinants of such differential responses.

Land management related to intensive dairy agriculture in lowland of the Northwest of Portugal has produced landscape mosaics composed of disperse settlements and small forest patches scattered throughout an intensive cropland matrix (Lomba et al., 2011). Traditionally dominated by maritime-pine (Pinus pinaster Ait.), and functionally coupled with agriculture (e.g. see Fangueiro et al., 2008), these patches have lost most of their economic and cultural importance, and are currently used as waste areas or have been converted to small-scale or industrial-scale forestry, with the latter being more frequent in the larger stands (Lomba et al., 2010; Mendes, 2007). Agricultural intensification and landscape fragmentation (Gonzalez et al., 2010; Lomba et al., 2010), together with an increasing density in urban and peri-urban areas (e.g. Gonzalez et al., 2010), underpin a pressing need of analytical frameworks to assess the potential of forest remnants in agricultural landscapes as refuges for regional native plant diversity (Godefroid and Koedam, 2003b; Cayuela et al., 2006; van Halder et al., 2008; Lomba et al., 2011). Such frameworks should consider the heterogeneity of conditions in forest patches which can be common at regional scales (Godefroid and Koedam, 2003b; Benayas et al., 2008; van Halder et al., 2008). Here a hierarchical approach is proposed to achieve a deeper understanding on the relationship between plant species richness and patch area (SAR) of small forest islets in intensive farmland, and to address the impacts of decreasing forest naturalness on such relationships. The proposed analytical framework consists of two major steps defined by the set of forest patches used in each analysis. The first step, corresponding to the first research question and level of analysis, focused on the assessment of regional SARs for the whole set of surveyed patches. The second step (i.e. second research question and level of analysis) dissected regional SARs within forest types (Pinus dominated stands, Eucalyptus dominated stands and mixed Pinus and Eucalyptus). Additionally, the same approach was applied to SARs of species groups according to their biogeographic origin (native versus alien plant species) and growth habit (herbaceous versus woody species). Finally, implications of the results are discussed in the context of landscape planning and management.

\section{Methods}

\subsection{Study area}

The study was conducted in the "Entre-Douro-e-Minho" Dairy Farming Region, part of the highly urbanised Metropolitan Area of Porto, in the Northwest of Portugal $\left(8^{\circ} 48^{\prime}-8^{\circ} 18^{\prime \prime} \mathrm{W}, 41^{\circ} 39^{\prime}-\right.$ $41^{\circ} 10^{\prime \prime} \mathrm{N}$; Fig. 1). In this intensive farming area, elevation ranges from sea-level along the coast to ca. $500 \mathrm{~m}$, mean annual temperature ranges from 13 to ca. $15^{\circ} \mathrm{C}$, and mean annual precipitation shows a west-east gradient from 1160 to $1458 \mathrm{~mm}$. Dominant bedrock types are granite and schist, both generating acid, nutrient poor soils, with sandy soils occurring along the coast and alluvial soils in narrow strips along main rivers. This area is quite homogeneous in terms of climate, geology and topography, and so it was considered suitable to address the effects of spatial and structural features on the patterns of biodiversity in forest stands (Lomba et al., 2011).

Due to high levels of urbanisation and intensive agricultural practices (Lomba et al., 2011), the current landscape of the study area is a highly simplified mosaic, in which large annual crop stands devoted to forage production are dominant. Since urban expansion coexists with intensive dairy farming practices, frequent changes in land use occur. Patterns of land cover and the associated land use are influenced by local terrain morphology, with intensive dairy farming mostly located in valleys and on gentle slopes where suitable soils are more frequent, and industrial forestry mainly of Eucalyptus globulus Labill. (exotic) and P. pinaster Aiton (native but mostly planted), developed on slopes with drier, nutrient-poor soils. Whereas the larger forest stands are usually dominated by Eucalyptus and are always devoted to industrial exploitation, the smaller forest fragments (which can be dominated by Eucalyptus and/or Pinus) are found scattered within the agricultural landscape, typically surrounded by forage annual crops.

In these landscape mosaics, small forest stands were historically used as complementary to dairy agricultural practices, as sources of fuel or heath for cattle bedding; more recently, they are often used as excess manure deposition areas (Mendes, 2007; Lomba et al., 2010, 2011). In recent decades, with external inputs of synthetic fertilizers, forest patches have lost most of their economic and cultural importance, and they are currently used as waste areas or have been converted to small-scale industrial forestry based on the exotic blue-gum tree (E. globulus Labill.) (Mendes, 2007; Lomba et al., 2011). Eucalypt stands in the study area are always related to intensive wood production for the pulp industry. They are considered profitable regardless of their size and provided that they are managed by land owners (e.g. to promote the growth 


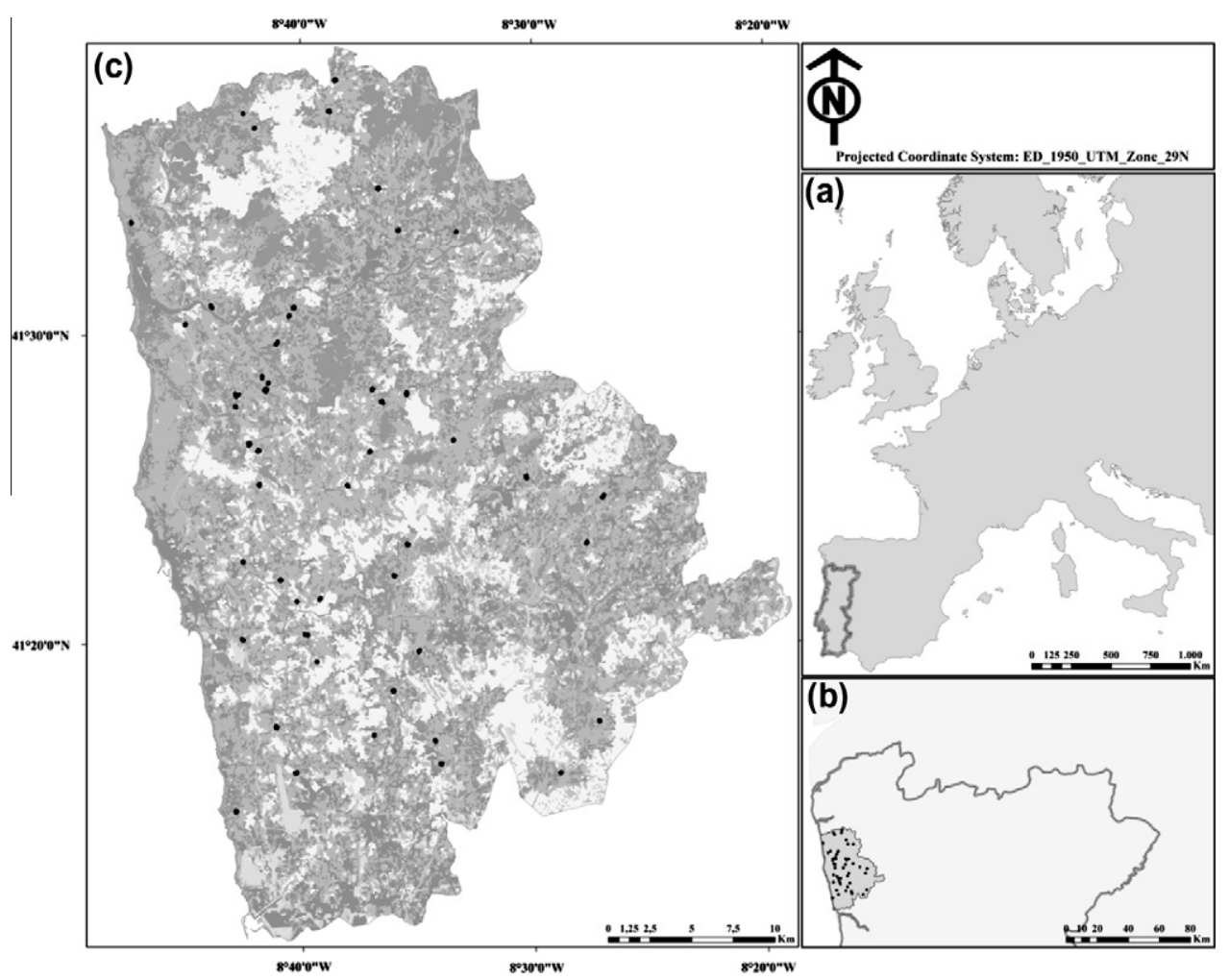

Fig. 1. The study area in the European (a) and regional (b) contexts, and location of the surveyed forest patches (c).

of trees and to control fire hazard). Conversely, small pine forests are usually not managed so intensively and no significant variations were recognised within the patch size range surveyed for this study (see Section 2.2).

Eucalyptus is a fast growing tree, for which several types of impacts have been reported when managed under intensive forestry practices, e.g. depletion of soil nutrients, breakdown of soil structure (affecting the water-holding capacity of the soil, Jones et al., 1999), production of allelopathic compounds (Briones and Ineson, 1996), root competition and tree canopy cover effects (Carneiro et al., 2008), and a decrease of plant species richness. Nonetheless, vegetation structure in the targeted forest stands, reflected for instance in tree density and understory vegetation cover, is mostly determined by human management (Lomba et al., 2011). Urban areas form a fairly continuous network along the coast, spreading along the main roads and river valleys into the more interior rural areas. Natural vegetation, usually quite disturbed, is restricted to discontinuous riparian habitats along streams and rivers, and to edges and clearings of forest stands.

\subsection{Sampling design and data collection}

In order to sample forest stands in landscape mosaics along a gradient of agricultural use, we determined the percentage cover of annual crops per $1 \mathrm{~km}^{2}$ grid cell (Lomba et al., 2010), based on a land cover map of the study area (1:25,000 scale; http://sitgaideg.xunta.es/proxectosign/). From the set of grid cells presenting more than $20 \%$ of annual crops, 50 forest stands were randomly selected, ranging from 3000 to $30,000 \mathrm{~m}^{2}$ in surface area (Fig. 1). We defined that, in cases of total unfeasibility of surveying any of the randomly selected forest stands (e.g. due to clearing, land use conversion, or restricted access), the nearest forest stand with a similar area would be surveyed.

In each forest stand the presence of all vascular plant species was recorded following a nested centralised approach. To do so, in each patch exhaustive standardised surveys starting with a $10 \mathrm{~m}^{2}$ central square were performed, through gradual nested increases to $10^{2} \mathrm{~m}^{2}, 10^{3} \mathrm{~m}^{2}$ (for stands reaching that size), all centred in the stand centroid, and finally the whole extent of the stand. In all nested areas, full species lists were recorded for vascular plants (native and exotic). Field surveys were performed by multiple surveyors covering distinct sections of the patch being surveyed, thereby ensuring thorough survey of the patch. The described procedure assured a standardised approach across patches and a complete survey of each individual patch. Species nomenclature followed that of Flora Iberica (Castroviejo et al., 1986-2010). See Appendix B for a complete list of recorded species, taxonomic considerations and classification of plant species. Finally, all stands were described according to their tree canopy species composition in order to support a classification of stands into forest types according to dominant tree species (see Section 2.4).

\subsection{Analytical framework}

Here a hierarchical approach was used to achieve a deeper understanding on the relationship between species richness and patch area (SARs) of small forest islets in intensive farmland and to address the impacts of decreasing naturalness on such relationships (Fig. 2). The proposed analytical framework consisted of two major steps defined by the set(s) of forest patches (i.e. samples) used in each analysis: (i) the first step (general patterns) focused on the analysis of relations between plant species richness and area for the whole set of 50 patches/samples (step [1], Fig. 2), whereas (ii) the second step (specific patterns) dissected SARs within forest types (step [2], Fig. 2). Within each of the two steps, two types of analyses were developed: (i) an inter-patch analysis, in which the SAR was determined for the whole set of patches (step [1a], Fig. 2) and for the set of patches belonging to each forest type (step [2a], Fig. 2); and (ii) an intra-patch analysis, in which SARs were assessed across the 


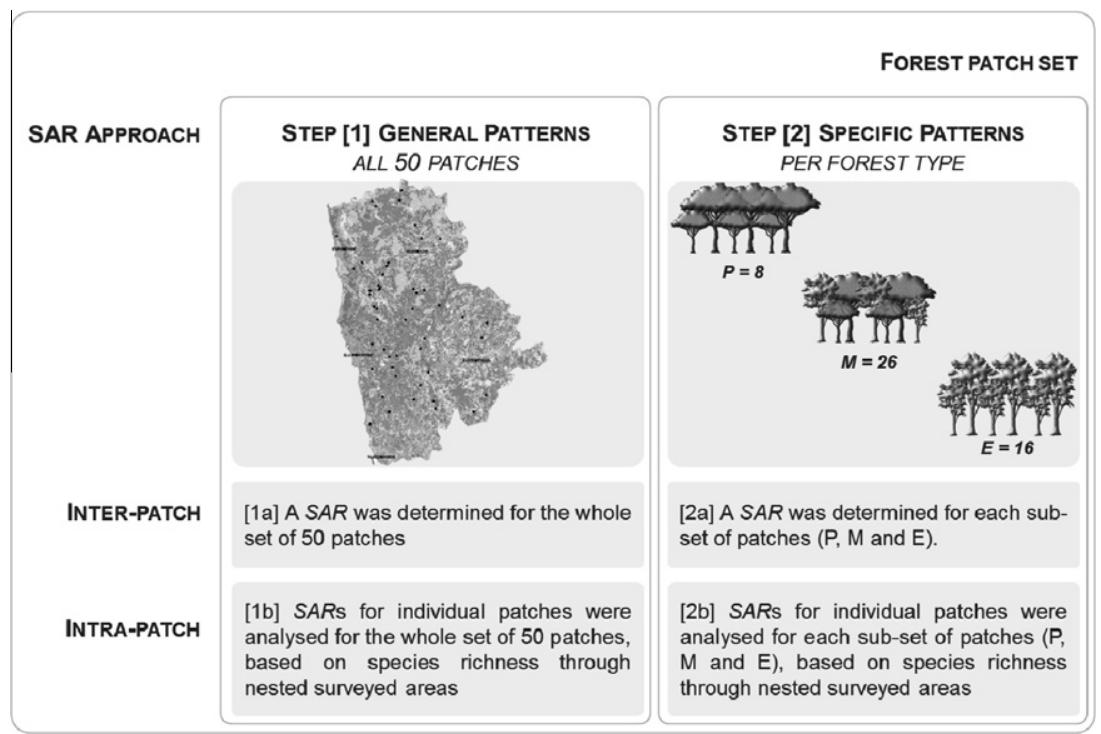

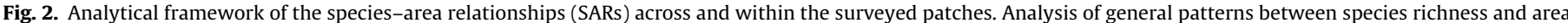

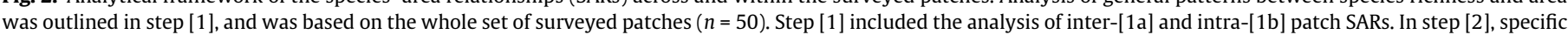

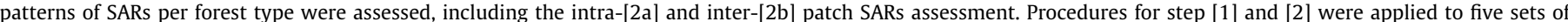

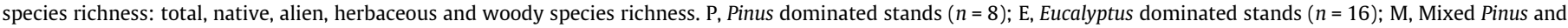
Eucalyptus stands $(n=26)$.

nested surveyed areas $\left(10 \mathrm{~m}^{2}, 10^{2} \mathrm{~m}^{2}, 10^{3} \mathrm{~m}^{2}\right.$ and the whole extent of the patch as described in Section 2.2) for each individual patch and analysed within each forest type (step [2b]; Fig. 2) and across forest types (i.e. for the whole set of 50 samples; step [1b], Fig. 2). In order to test for differential relationships within species groups against stand area (e.g. see Zschokke et al., 2000), all these analyses were performed considering five groups of species from the whole floristic dataset: (i) total species richness $\left(S_{t}\right)$, (ii) native species richness $\left(S_{\text {native }}\right)$, (iii) alien species richness $\left(S_{\text {alien }}\right)$, (iv) herbaceous species richness $\left(S_{\text {herb }}\right)$ and $(v)$ woody species richness $\left(S_{\text {woody }}\right)$ (see detailed description in Section 2.4).

The analysis of general patterns (step [1], Fig. 2) aimed to determine variations in species-area relationships (SARs) for the whole set of surveyed patches $(n=50)$. SARs were first assessed across patches, by determining the relationship between species richness and the whole patch area - inter-patch SARs (step [1a], Fig. 2; Battles et al., 2001; Atauri et al., 2004; Proença et al., 2010). Also intrapatch SARs were calculated (step [1b], Fig. 2), based on species richness data and area from each of the nested surveyed areas (Proença et al., 2010; see Section 2.2).

The impact of forest naturalness on species-area relationships (i.e. specific patterns) was assessed in step [2] (Fig. 2) by analysing SARs within and across forest types. First, the total set of patches $(n=50)$ was allocated according to the dominant canopy tree into: (i) Pinus dominated stands (P; $n=8$ ), (ii) Eucalyptus dominated stands (E; $n=16$ ), and (iii) mixed Pinus and Eucalyptus stands (M; $n=26)$. Such classification reflected a gradient of forest naturalness, from semi-natural stands dominated by the native (though mostly widespread by landowners in the region for forestry) maritime-pine, to the mixed Pinus and Eucalyptus stands, and finally to the more intensively managed stands dominated by Eucalyptus. For the inter-patch level (step [2a], Fig. 2), SARs were determined considering, for each set of forest patches, the relationship between species richness and total surface area of each patch. Intra-patch SARs (step [2b], Fig. 2) were determined for species richness and area using the four nested areas surveyed in each patch (for more details see Section 2.2), for each of the considered forest patch sets.
Inter- and intra-patch SARs were compared across the considered species groups in the assessment of general and specific patterns.

\subsection{Statistical analyses}

Each surveyed stand was assigned to a specific forest type (Appendix A) based on the dominant tree species, obtained from the relative abundance of $P$. pinaster and E. globulus. As recommended by Ferreira et al. (2005; http://www.afn.min-agriculture.pt), we used a minimum value of $75 \%$ percentage cover for a dominant tree, or then the absence of a clear dominant species, and classified our stands accordingly. As a result of this classification, from the total number of forest stands $(n=50)$, we obtained: (i) Pinus dominated stands (P; $n=8$ ), (ii) mixed Pinus and Eucalyptus stands (M; $n=26$ ), and (iii) Eucalyptus dominated stands (E; $n=16$ ). Even if unbalanced, this set of surveyed stands spanned throughout the whole range of variation and was considered suitable to address our research questions, as it expresses a gradient of forest naturalness, from the pure stands dominated by the native $P$. pinaster, mixed stands in which the two species are co-dominant, to pure stands of the exotic E. globulus.

The recorded plant species were classified on the basis of their biogeographic origin (native or alien/exotic) and according to a simplified life form classification as herbaceous (herb) and woody plants (Bunce et al., 2008; see Appendix B for the complete list of recorded species, taxonomic considerations and plant species classification). Hence, the following dependent variables were defined: (i) total species richness $\left(S_{t}\right)$, (ii) native species richness $\left(S_{\text {native }}\right)$, (iii) alien species richness ( $\left.S_{\text {alien }}\right)$, (iv) herbaceous species richness $\left(S_{\text {herb }}\right)$ and $(\mathrm{v})$ woody species richness ( $\left.S_{\text {woody }}\right)$.

Species-area relationships (SARs) were obtained through the application of two types of regression models: the power model, as described by Arrhenius ( $S=c^{*} A^{z}$; Tjørve and Tjørve, 2008; Tjørve, 2011); and the exponential or semi-log model, as described by Gleason $(S=c+z \log (A)$; Tjørve and Tjørve, 2008; Tjørve, 2011). In both equations, $S$ expresses the number of species, $A$ is the area, and $c$ and $z$ are the parameters of the model, which represent the constant (here, the intercept where area $(A)$ is $10 \mathrm{~m}^{2}$ ) and the slope 
obtained through regression analysis, respectively (Morgan et al., 2011). The power model was evaluated in its log-log form (log$\log$ model), $\log S=\log c+z \log A$ (Tjørve and Tjørve, 2008; Tjørve, 2011), and for both models species data were log transformed $(S+1$; Proença et al., 2010; Tjørve, 2011).

The fit of species-area relationship to the power model and to the exponential model was assessed through the comparison of the $z$-values, as they provide information on the steepness of the relationship between species richness and area, their statistical significance (expressed as $p$ values) and respective values of $r^{2}$ (Tjørve, 2009; Proença et al., 2010; Morgan et al., 2011). Overall, the power model was better adjusted to species-area data in both the inter- and intra-patch analyses, which resulted in significant relations $(p<0.05)$ and higher values of $r^{2}$. Therefore, only results for the power models are presented and discussed in later sections.

Kruskal-Wallis and post-hoc Mann-Whitney $U$ tests were used to detect significant differences of $z$-values (model slope; Tjørve and Tjørve, 2008) for intra-patch SAR analyses (applied to the three forest types and five response variables derived from species dataset).

Values of species richness presented throughout the text are expressed as median \pm quartile range. All the analyses were performed using STATISTICA ${ }^{\circledR}$.

\section{Results}

\subsection{Patterns of plant species richness}

Overall, 253 plant species were recorded across the surveyed forest stands, of which 220 were native $(87.00 \%)$ and 198 were herbaceous (78.30\%). Each stand exhibited a median value of $37.00 \pm 14.50$ species, of which only $4.00 \pm 2.00$ corresponded to alien and $14.50 \pm 5.00$ to woody plant species.

Forest stands dominated by Pinus exhibited higher values of median species richness $\left(S_{\mathrm{t}}=46.50 \pm 26.50\right)$, followed by mixed $\mathrm{Pi}$ nus and Eucalyptus stands $\left(S_{\mathrm{t}}=36.00 \pm 16.00\right)$ and finally those dominated by Eucalyptus $\left(S_{\mathrm{t}}=35.50 \pm 19.50\right)$. Similar patterns were found for native $\left(S_{\text {native }}\right)$, woody $\left(S_{\text {woody }}\right.$ and herbaceous $\left(S_{\text {herb }}\right)$ species richness. An exception was however found for alien species, which had highest median values for species richness in Eucalyptus stands, followed by Pinus stands and finally by mixed stands.

Eucalyptus $\left(11261.00 \pm 5572.40 \mathrm{~m}^{2}\right)$ and mixed $(10887.90 \pm$ $6242.00 \mathrm{~m}^{2}$ ) forests exhibited the highest median values for patch area, when compared to the somewhat smaller Pinus stands $\left(9781.40 \pm 4477.00 \mathrm{~m}^{2}\right)$. Further details on areas and species richness of each surveyed stand can be found in Appendix A.

\subsection{General patterns of species-area relationships}

Analyses of variation of median species richness $\left(S_{t}\right)$ with surveyed area within individual patches (Fig. 3 ) revealed significant differences for total species $\left(S_{t}\right)$ between forest types at the lowest $\left(10 \mathrm{~m}^{2}\right)$ and intermediate $\left(10^{3} \mathrm{~m}^{2}\right)$ surveyed areas. For the smallest surveyed area, stands dominated by Pinus hosted more species $\left(S_{\mathrm{t}}=9.00 \pm 4.00\right)$ than both mixed Pinus and Eucalyptus $\left(S_{\mathrm{t}}=\right.$ $8.00 \pm 2.00)$ and Eucalyptus dominated stands $\left(S_{\mathrm{t}}=6.5 \pm 3.00\right)$. At the intermediate area surveyed $\left(10^{3} \mathrm{~m}^{2}\right)$, Pinus stands also hosted more species $\left(S_{t}=22.00 \pm 10.00\right)$ than mixed Pinus and Eucalyptus stands $\left(S_{\mathrm{t}}=15.00 \pm 4.00\right)$.

SAR assessments first focused on putative relationships between species richness and area across the whole set of patches (step [1], Fig. 2). Regression models for the inter-patch level of analysis, i.e. based on the total area of each patch for the whole set of patches (step [1a], Fig. 2), were not statistically significant, expressed as $p>0.05$ in all cases (Table 1 ). In the case of woody

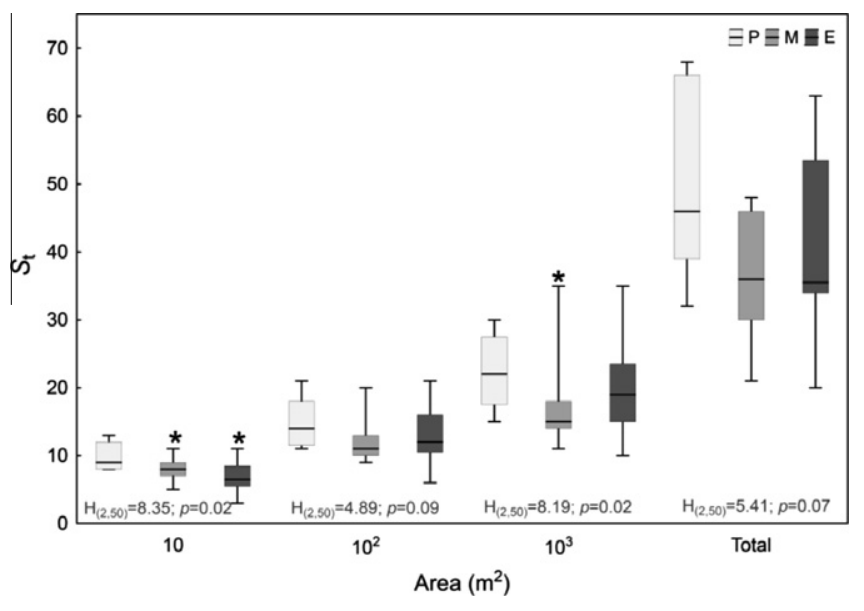

Fig. 3. Variation of median species richness $\left(S_{t}\right)$ with increasing values of area $\left(10 \mathrm{~m}^{2}, 10^{2} \mathrm{~m}^{2}, 10^{3} \mathrm{~m}^{2}\right.$ and the whole extent of the stand - "Total") for each of the considered forest types. P, Pinus dominated stands; M, mixed Pinus and Eucalyptus stands; and, E, Eucalyptus dominated stands. Boxes represent the 25th and 75th percentiles, whereas whiskers represent the 5th and 95th percentiles. Results for Kruskal-Wallis, $\mathrm{H}$ (degrees of freedom, number of samples) and $p$ are embedded in the figure; $\left({ }^{*}\right)$ identifies statistically significant differences from Pinus dominated stands (Mann-Whitney test; $p<0.05$ ).

\section{Table 1}

Results of the inter-patch analysis of species-area relationships obtained for the whole set of 50 patches (step [1a], Fig. 2) and for each group of plant species: total $\left(S_{t}\right)$, native $\left(S_{\text {native }}\right)$, alien $\left(S_{\text {alien }}\right)$, herbaceous $\left(S_{\text {herb }}\right)$ and woody $\left(S_{\text {woody }}\right)$. The values of $z, c$ $r^{2}$ and $p$ are shown and represent the slope, the constant, the regression coefficient and the statistical significance of the regression model $(\log (S+1)=\log c+z \log A)$ respectively.

\begin{tabular}{lrrrrr}
\hline Model parameters & \multicolumn{1}{l}{$S_{\mathrm{t}}$} & $S_{\text {native }}$ & \multicolumn{1}{c}{$S_{\text {alien }}$} & \multicolumn{1}{c}{$S_{\text {herb }}$} & $S_{\text {woody }}$ \\
\hline$z$ & -0.02 & -0.03 & 0.10 & -0.14 & 0.28 \\
$c$ & 1.67 & 1.66 & 0.08 & 2.01 & -0.08 \\
$r^{2}$ & 0.00 & 0.00 & 0.01 & 0.03 & 0.08 \\
$p$ & 0.84 & 0.77 & 0.50 & 0.21 & 0.06 \\
\hline
\end{tabular}

species richness a $p$-value close to the considered significance level ( $p=0.06$; Table 1 ) was nonetheless achieved.

Intra-patch SAR (step [1b], Fig. 2) for each individual stand, fitted from the four nested areas and the corresponding species richness values within each stand, were found to result in significant regression models $(p<0.05)$ for total species richness $\left(S_{t}\right)$ and for all species groups (native, alien, herbaceous, and woody). $z$-Values ranged between 0.04 and 0.33 (see Fig. 4), with native species and herbaceous species exhibiting the highest median $z$-values $(0.21 \pm 0.05$ and $0.21 \pm 0.07$, respectively), followed by woody species $(0.18 \pm 0.06)$ and alien species $(0.14 \pm 0.12)$. Results from Mann-Whitney tests highlighted significant differences for median $z$-values between the first two groups (native and herbaceous) and the latter two groups (alien and woody; $p<0.001$ ), respectively. Native species richness is therefore more sensitive to area than alien species richness, and the same happened for herbaceous species richness when compared with woody species richness.

\subsection{Specific patterns for the species-area relationships}

In the second step (specific patterns), species-area relationships were addressed within forest types (step [2], Fig. 2). Overall, results for the inter-patch analysis, corresponding to a SAR value per forest type and species group (step [2a], Fig. 2), were found to be non-significant (Table 2). However, values close to the established significance level were observed for herbaceous species richness in 


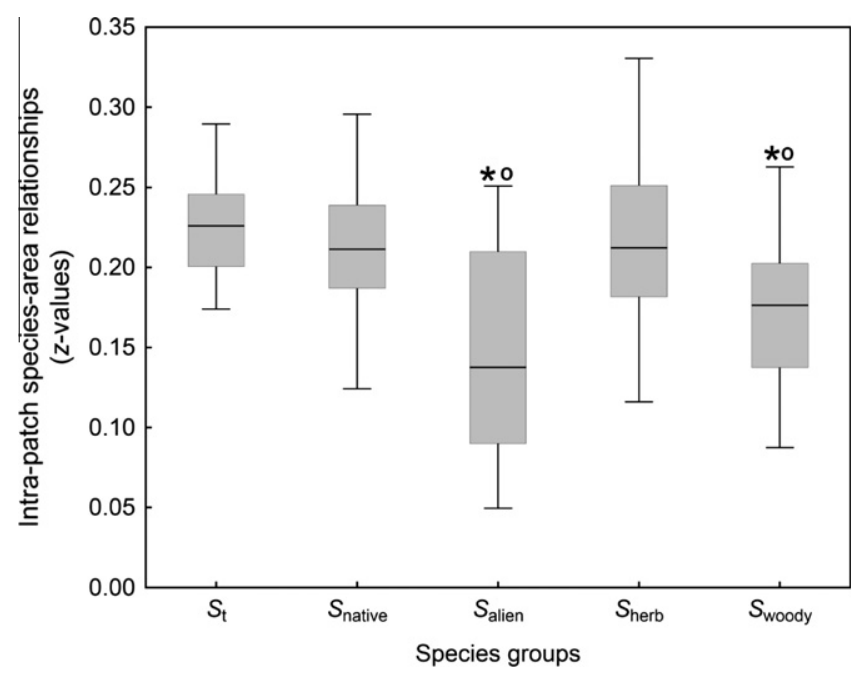

Fig. 4. Intra-patch analysis of the species-area relationships ( $z$ values) obtained for the whole set of 50 patches (step [1b], Fig. 2) and for each group of plant species: total $\left(S_{t}\right)$, native $\left(S_{\text {native }}\right)$, alien $\left(S_{\text {alien }}\right)$, herbaceous $\left(S_{\text {herb }}\right)$ and woody $\left(S_{\text {woody }}\right)$. The vertical axis expresses median $z$-values; boxes represent the 25th and 75th percentiles, whereas whiskers depict the 5th and 95th percentiles. Differences between species groups (Mann-Whitney test; $p<0.01$ ) are represented by distinct symbols, $\left({ }^{*}\right)$ identifies statistically significant differences between $S_{\text {native }}$ and marked species groups, whereas $\left(^{\circ}\right)$ identifies statistically significant differences between $S_{\text {herb }}$ and marked species groups.

mixed forest stands, and for woody species richness in Eucalyptus dominated stands ( $p=0.07$; Table 2 ).

Conversely, when analysing intra-patch SARs per forest type (step [2b], Fig. 2), all SARs resulted in significant relationships (Fig. 5). Post-hoc comparisons of $z$-values between pairs of forest types revealed that significant differences were only found between $z$-values for Eucalyptus dominated and mixed stands, in the cases of total $\left(S_{t}\right)$ and woody $\left(S_{\text {woody }}\right)$ species richness $(p<0.05)$.

\section{Discussion}

\subsection{Plant species richness and forest naturalness}

The increase of plant species richness along a gradient of increasing forest naturalness had already been described by Lomba et al. (2011) for the dairy farmlands of the Northwest of Portugal. Stands where the native $P$. pinaster was the dominant tree species exhibited higher values for total $\left(S_{\mathrm{t}}\right)$, native $\left(S_{\text {alien }}\right)$, woody $\left(S_{\text {woody }}\right)$ and herbaceous $\left(S_{\text {herb }}\right)$ species richness (cf. Appendix A). Overall, these results are in agreement with those reported in previous research which revealed differences between forest stands exhibiting different levels of naturalness e.g. for temperate forests (e.g. Battles et al., 2001; Atauri et al., 2004; Proença et al., 2010). The nature of the canopy, expressed as the dominant tree, has been consistently stressed (e.g. Godefroid et al., 2005) as a determinant of plant species richness at the ground level, namely for herbs and shrubs, due to its influence on the radiation that arrives to the ground level and even on soil characteristics (Estevan et al., 2007; Augusto et al., 2002).

Stands dominated by the exotic E. globulus present the lowest values for native species richness $\left(S_{\text {native }}\right)$, which is also consistent with previous reports on the reduction of floristic diversity in eucalypt plantations (e.g. see Briones and Ineson, 1996; Carneiro et al., 2008; Lomba et al., 2011). Additionally, in the study area eucalypt plantations hosted the highest values for alien species richness $\left(S_{\text {alien }}\right)$. In these forest stands, the lower values of native species richness (cf. Appendix A) may be promoting alien invasion by decreasing community saturation and biotic resistance, making the undergrowth of eucalypt stands more susceptible to colonisation by new species (Carneiro et al., 2008; Lomba et al., 2011). The effect of patch isolation was not considered since in general each of the targeted patches was immersed in an agricultural matrix, sometimes in contact with urban areas, only occasionally near other forest areas. Overall, patch attributes related to management intensity (together with edge effects, which are considerable in these small forest patches; see Fig. 3) appear to be key factors in explaining patch species richness (Lomba et al., 2011).

\subsection{Inter-patch species-area relationships}

Total patch size was found not to be an important determinant of plant species richness across the analysed set of woodlots. This was expressed in the absence of significant relationships between species richness and total patch area for both general (i.e. for the whole set of patches) and specific (i.e. per patch type) SAR patterns (step [1a] and [2a]; cf. Tables 1 and 2, respectively). This suggests that, since small forest patches were selected for analysis, the range of stand sizes may be outside the values for which there is dependency of forest specialists on patch area (Rodríguez-Loinaz et al., 2012). Moreover, understory colonisation by generalist plant species from the surrounding farming matrix may be homogenising species assemblages thereby obscuring any possible effects of area over forest specialists (e.g. see Rodríguez-Loinaz et al., 2012).

There could be many reasons for the absence of significant inter-patch SARs, from isolation and other landscape attributes to current and former use and management (e.g. see Ewers and Didham, 2006; Gonzalez et al., 2010). Conversion and fragmentation caused by human activities have been identified as the most important drivers of change in forest plant diversity (e.g. see Trisorio et al., 2010; Jamoneau et al., 2012). In such context, though patch area has been referred as positively correlated to plant species richness (e.g. forest species, Økland et al., 2006; Trisorio et al., 2010; Żmihorski et al., 2010), this was not the case for the studied woodlots, and other factors may be influencing species richness in the studied area, as mentioned previously for the same region (Lomba et al., 2010, 2011). Proença et al. (2010) reported the

Table 2

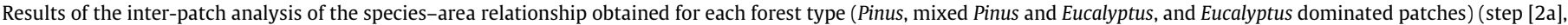

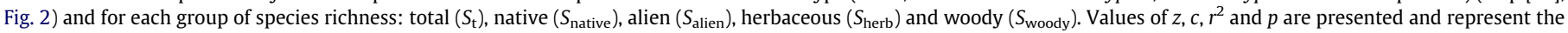
slope, the constant, the regression coefficient and the statistical significance of the regression $\operatorname{model}(\log (S+1)=\log c+z \log A)$, respectively.

\begin{tabular}{|c|c|c|c|c|c|c|c|c|c|c|c|c|}
\hline & \multicolumn{4}{|c|}{ Pinus forest stands } & \multicolumn{4}{|c|}{ Mixed forest stands } & \multicolumn{4}{|c|}{ Eucalyptus forest stands } \\
\hline & $z$ & $c$ & $r^{2}$ & $p$ & $z$ & $c$ & $r^{2}$ & $p$ & $z$ & $c$ & $r^{2}$ & $p$ \\
\hline$S_{\mathrm{t}}$ & -0.44 & 3.46 & 0.19 & 0.28 & 0.19 & 0.80 & 0.07 & 0.31 & -0.08 & 1.89 & 0.03 & 0.43 \\
\hline$S_{\text {native }}$ & -0.50 & 3.63 & 0.22 & 0.24 & -0.10 & 1.90 & 0.03 & 0.36 & 0.21 & 0.69 & 0.10 & 0.24 \\
\hline$S_{\text {alien }}$ & 0.23 & -0.32 & 0.03 & 0.68 & 0.07 & 0.18 & 0.01 & 0.71 & 0.07 & 0.24 & 0.00 & 0.83 \\
\hline$S_{\text {herb }}$ & 0.33 & -0.16 & 0.17 & 0.31 & 0.57 & -1.34 & 0.20 & 0.07 & 0.21 & 0.19 & 0.10 & 0.22 \\
\hline$S_{\text {woody }}$ & -0.80 & 4.71 & 0.26 & 0.19 & 0.11 & 1.02 & 0.02 & 0.61 & -0.24 & 2.33 & 0.13 & 0.07 \\
\hline
\end{tabular}


(a)

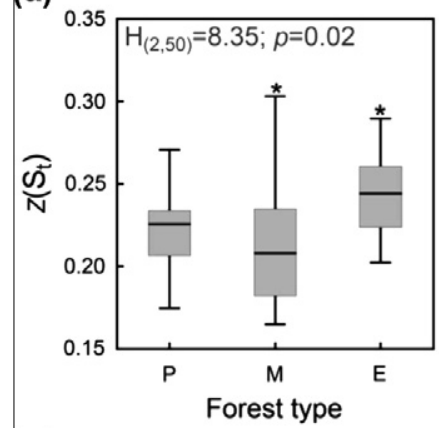

(d)

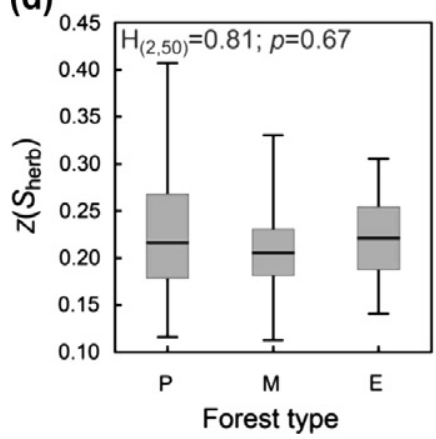

(b)

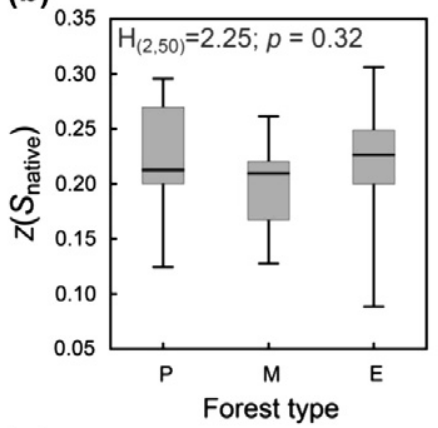

(e)

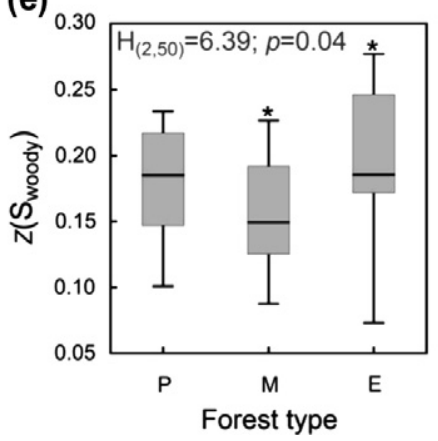

(c)

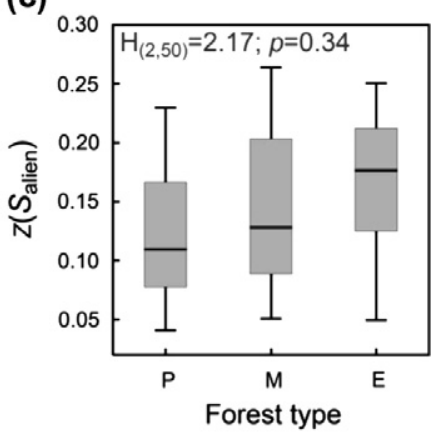

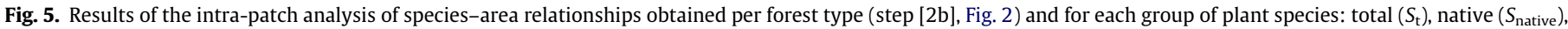

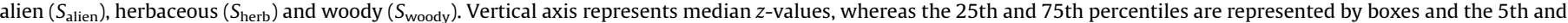

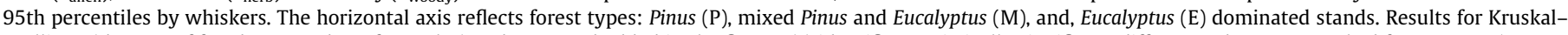

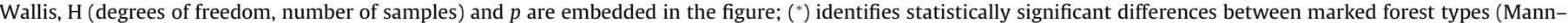
Whitney test; $p<0.05$ ).

absence of significant inter-patch species-area relationships in the case of plants for oak forest patches, and Pine and Eucalypt stands. Also Simberloff and Gotelli (1984; see Lawesson et al., 1998) described from studies in the American prairie-forest ecotone that the total of several small sites tend to contain more species than do single larger ones with the same total area, and that small sites tend to have more species than larger sites, which often host fewer species than expected. Among possible reasons for the absence of such patterns are the differences related to life-history traits in species responses e.g. weak correlation between stand area and richness for forest-floor plants (Yamaura et al., 2008), different contribution from forest interior versus edge habitats (e.g. Gonzalez et al., 2010), and the known impacts of land-use history in patterns of species richness, particularly in the case of maintenance of environmental heterogeneity within stands even when their area decreases (e.g. see Bruun, 2000; Jamoneau et al., 2012).

Even if in apparent disagreement with SAR patterns described in previous research (e.g. Lomolino, 2000; Dolnik and Breuer, 2008), the increase of patch area in the dairy farmlands of the Northwest of Portugal appears to be directly connected to shifts in forest management (Lomba et al., 2010, 2011; Proença et al., 2010). More specifically, the shift towards industrial management of eucalypt plantations has involved an increase in stand size, thus it appears that the putative positive effect of forest area may be masked by the negative effect of eucalypts (and of the related intensive management regime) on the patterns of plant species richness (e.g. see Atauri et al., 2004; Lomba et al., 2011). Lomba et al. (2011) described similar patterns in a previous research which aimed to address the joint and independent effects of dominant tree species, forest patch spatial attributes, and forest structure and management as drivers of plant species richness and composition in small forest patches scattered within intensive agricultural landscapes of north-west Portugal.

\subsection{Intra-patch species-area relationships}

Whilst no relation was found for inter-patch SARs, this was not the case for intra-patch analyses, both for the whole set of forest patches (step [1b], Fig. 2) and across forest types (step [2b], Fig. 2). In fact, significant intra-patch SARs $(p<0.05)$ were obtained for all species groups (cf. Fig. 4). Values of SAR slopes ( $z$-values), recognised as adequate tools for the interpretation of species richness responses to area (e.g. see Dolnik and Breuer, 2008), revealed that the strongest intra-patch increases of species richness with area occurred for native species and for herbaceous species, significantly different from $z$-values for woody and alien species richness (cf. Fig. 3). These different patterns obtained for distinct species groups are consistent with those described by Gonzalez et al. (2010) and Rodríguez-Loinaz et al. (2012). In their research, these authors highlighted differential responses of plant species regarding forest interior versus forest edges, e.g. forest habitat specialists from interior areas show a positive relationship with an increase in area, while generalists show no relationship and edge species were described as negatively responding to woodlot area. Also, Lawesson et al. (1998) reported differential responses of species groups to patch size, emphasising the fact that few species groups present significant patterns consistent with increases in forest area.

According to some authors (e.g. those advocating the "habitat diversity hypothesis", Jamoneau et al., 2011), area is actually a surrogate for environmental heterogeneity, and even reduced patch sizes, often detrimental to habitat specialists, can be suitable for a number of species from neighbouring open habitats (as those present in agricultural landscapes; Lomba et al., 2011). Our results suggest frequent colonisation of forest edges by herbaceous native species from the surrounding farmland matrix, which is promoted by continuous propagule pressure and decreased biotic resistance of managed stands (Petit et al., 2004; Jamoneau et al., 2011; Rodríguez-Loinaz et al., 2012). 
Ecological conditions of forest patches represent, together with plant species dispersal ability, important limiting factors for species occurrence in fragmented landscapes (Petit et al., 2004; Guirado et al., 2007; Lomba et al., 2011). Stand structural properties (e.g. forest structure, canopy cover, Estevan et al., 2007), disturbance regime, management and spatial attributes (e.g. patch area, Guirado et al., 2008; Yamaura et al., 2008); shape, Saura and Cabral, 2004) are some of the factors that have been considered as determinants of the species pool colonising forest fragments. Also, characteristics related to the dominant species in the canopy (e.g. see Augusto et al., 2002; Lomba et al., 2011) have been related to distinct understory composition (e.g. by influencing the radiation that arrives to the ground level or even soil characteristics; Augusto et al., 2002; Estevan et al., 2007) and frequently reflect long-term changes in land-use and in forest patch attributes (Estevan et al., 2007; Guirado et al., 2008).

\subsection{Implications for landscape management and planning}

Although the species-area relationship has been assumed as a general pattern across taxa (e.g. Lomolino, 2000), several studies have reported the absence of this relationship in forest fragments, e.g. for woody species (Cayuela et al., 2006). Land use history (e.g. see Bruun, 2000; Jamoneau et al., 2012), differential responses of species groups related to life-history traits (Kolb and Dieckmann, 2004; Ewers and Didham, 2006), and environmental heterogeneity within forest patches have been referred as some factors able to obscure such relationship (e.g. Jamoneau et al., 2011).

Total area of stands did not present any relationship with current patterns of species richness (for any of the targeted species groups) in the dairy farmlands of the Northwest of Portugal. Recent studies performed in these intensively managed landscapes highlighted the complexity of species richness patterns and pointed out the joint effect of several environmental and anthropic determinants (Lomba et al., 2010, 2011). The fact that the increase of patch area is not reflected in a significant increase of plant species richness (in some cases, an inverse tendency was even observed), seems to be related to shifts in the dominant tree species in the canopy, since there has been an increase of patch area associated with the intensification of management in forest stands following the plantation of exotic species (e.g. monocultures dominated by E. globulus, Proença et al., 2010; Lomba et al., 2011). Eucalypt plantations are those exhibiting higher values of total area, but also simpler shapes (Lomba et al., 2010, 2011), which together with intensive management practices may be determining the lower values of plant diversity. Conversely, the smaller woodlots dominated by maritime-pine (a widely planted native tree) usually present higher levels of plant diversity, which may be a result from the maintenance of environmental heterogeneity inside the patch. In fact, pine dominated stands present more complex shapes and more irregular structure (e.g. see Lomba et al., 2011), derived from the absence of intensive management regimes. This may be promoting their ability to maintain higher levels of plant diversity (particularly native and herbaceous species; cf. Figs. 4 and 5), even with smaller patch areas, highlighting the importance of maintaining some pine stands as refuges for plant diversity in intensive farmland. Their importance is further enhanced by the fact that they may act as source habitats in local landscapes, promoting a regular propagule pressure from native plant species towards sink habitats e.g. eucalypt stands (see e.g. Godefroid and Koedam, 2003a,b).

The analysis of the intra-patch SARs revealed, in general, significant relations between increasing (nested) areas and plant species richness for all three analysed forest types. This suggests that (i) further reductions of stand sizes due to conversion and fragmentation could have severe effects on plant diversity at the patch level, and (ii) an increase of stand sizes would promote plant diversity, provided that no significant shifts in management would follow. Eucalypt stands exhibited the strongest SARs, which seems to be expressing the significantly lower values of species richness at the core of eucalypt dominated stands when compared with the other forest types (see Fig. 3). Additionally, environmental conditions and heterogeneity within Pinus and mixed stands may promote the ability for more (native) species to persist at the core of stands. Conversely, alien invasive species seem to be less influenced by area and thus to be more uniformly distributed inside forest stands across all forest types, highlighting the importance of management regimes in determining the extent of invasion. In this regard, the fact that eucalypt stands hosted more alien species than other forest types suggests that moderate to strong disturbance may favour invasion by controlling biotic resistance and allowing invasive plants to take advantage of key life-history traits (e.g. Vicente et al., 2010).

Overall, our results highlight the fact that the dominant canopy tree and forest management intensity tend to buffer SARs among patches but not within patches. In such context, the maintenance of smaller and complex patches dominated by native species, under rather extensive practices of forest management, can provide important refuges for plant diversity in the intensive dairy farmland as the one studied here. Even if smaller, they still allow the maintenance of high levels of native plant diversity (even if with an important proportion of habitat generalists), while at the same time contributing to limit the expansion of problematic alien invasive species.

\section{Acknowledgements}

A. Lomba is supported by the Portuguese Science and Technology Foundation (FCT) through Post-Doctoral Grant SFRH/BPD/ 80747/2011. J.P. Honrado received support from FCT through project grant PTDC/AGR-AAM/104819/2008 (EcoSensing). The authors would like to thank Paulo Alves for his assistance during field work and J. Alonso for making available the land cover map of the study area (Project SIGNII; http://sitgaideg.xunta.es/proxectosign).

\section{Appendix A and B. Supplementary material}

Supplementary data associated with this article can be found in the online version, at http://dx.doi.org/10.1016/j.foreco.2012. 11.012.

\section{References}

Atauri, J.A., de Pablo, C.L., de Agar, P.M., Schmitz, M.F., Pineda, F.D., 2004. Effects of management on understory diversity in the forest ecosystems of northern Spain. Environmental Management 34, 819-828.

Augusto, L., Ranger, J., Binkley, D., Rothe, A., 2002. Impact of several common tree species of European temperate forests on soil fertility. Annals of Forest Science 59, 233-253.

Battles, J.J., Shlisky, A.J., Barrett, R.H., Heald, R.C., Allen-Diaz, B.H., 2001. The effects of forest management on plant species diversity in a Sierran conifer forest. Forest Ecology and Management 146, 211-222.

Benayas, J.M.R., Bullock, J.M., Newton, A.C., 2008. Creating woodland islets to reconcile ecological restoration, conservation, and agricultural land use. Frontiers in Ecology and the Environment 6, 329-336.

Bengtsson, J., Nilsson, S.G., Franc, A., Menozzi, P., 2000. Biodiversity, disturbances, ecosystem function and management of European forests. Forest Ecology and Management 132, 39-50.

Briones, M.J.I., Ineson, P., 1996. Decomposition of eucalyptus leaves in litter mixtures. Soil Biology and Biochemistry 28, 1381-1388.

Bruun, H.H., 2000. Patterns of species richness in dry grassland patches in an agricultural landscape. Ecography 23, 641-650.

Bunce, R., Metzger, M., Jongman, R., Brandt, J., de Blust, G., Elena-Rossello, R., Groom, G., Halada, L., Hofer, G., Howard, D., Kovář, P., Mücher, C., Padoa-Schioppa, E., Paelinx, D., Palo, A., Perez-Soba, M., Ramos, I., Roche, P., Skånes, H., Wrbka, T., 2008. A standardized procedure for surveillance and monitoring European habitats and provision of spatial data. Landscape Ecology 23, 11-25. 
Carneiro, M., Fabião, A., Martins, M.C., Fabião, A., Abrantes da Silva, M., Hilário, L., Lousã, M., Madeira, M., 2008. Effects of harrowing and fertilisation on understory vegetation and timber production of a Eucalyptus globulus Labill. plantation in Central Portugal. Forest Ecology and Management 255, 591597.

Castroviejo J. et al., 1986-2010. Flora Iberica. Plantas Vasculares de la Península Ibérica e Islas Baleares. Real Jardín Botánico, CSIC, Madrid.

Cayuela, L., Benayas, J.M.R., Justel, A., Salas-Rey, J., 2006. Modelling tree diversity in a highly fragmented tropical montane landscape. Global Ecology and Biogeography 15, 602-613.

Dolnik, C., Breuer, M., 2008. Scale dependency in the species-area relationship of plant communities. Folia Geobotanica 43, 305-318.

Estevan, H., Lloret, F., Vayreda, J., Terradas, J., 2007. Determinants of woody species richness in Scot pine and beech forests: climate, forest patch size and forest structure. Acta Oecologica 31, 325-331.

Ewers, R.M., Didham, R.K., 2006. Confounding factors in the detection of species responses to habitat fragmentation. Biological Reviews 81, 117-142.

Fangueiro, D., Pereira, J., Coutinho, J., Moreira, N., Trindade, H., 2008. NPK farm-gate nutrient balances in dairy farms from Northwest Portugal. European Journal of Agronomy 28 (4), 625-634.

Ferreira, C., Carvalho, J., Baptista, M., 2005. Instruções para o trabalho de campo do inventário florestal nacional - IFN 2005/2006. In: Nacional, A.F. (Ed.), Direcção Nacional de Gestão Florestal. p. 68.

Godefroid, S., Koedam, N., 2003a. Distribution pattern of the flora in a peri-urban forest: an effect of the city-forest ecotone. Landscape and Urban Planning 65, 169-185.

Godefroid, S., Koedam, N., 2003b. How important are large vs. small forest remnants for the conservation of the woodland flora in an urban context? Global Ecology and Biogeography 12, 287-298.

Godefroid, S., Massant, W., Koedam, N., 2005. Variation in the herb species response and the humus quality across a 200-year chronosequence of beech and oak plantations in Belgium. Ecography 28, 223-235.

Golden, D.M., Crist, T.O., 1999. Experimental effects of habitat fragmentation on oldfield canopy insects: community, guild and species responses. Oecologia 118, 371-380.

Gonzalez, M., Ladet, S., Deconchat, M., Cabanettes, A., Alard, D., Balent, G., 2010 Relative contribution of edge and interior zones to patch size effect on species richness: an example for woody plants. Forest Ecology and Management 259, 266-274.

Guirado, M., Pino, J., Rodà, F., 2007. Comparing the role of site disturbance and landscape properties on understory species richness in fragmented periurban Mediterranean forests. Landscape Ecology 22, 117-129.

Guirado, M., Pino, J., Rodà, F., Basnou, C., 2008. Quercus and Pinus cover are determined by landscape structure and dynamics in peri-urban mediterranean forest patches. Plant Ecology 194, 109-119.

Honnay, O., Hermy, M., Coppin, P., 1999. Effects of area, age and diversity of forest patches in Belgium on plant species richness, and implications for conservation and reforestation. Biological Conservation 87, 73-84.

Jamoneau, A., Sonnier, G., Chabrerie, O., Closset-Kopp, D., Saguez, R., Gallet-Moron, E., Decocq, G., 2011. Drivers of plant species assemblages in forest patches among contrasted dynamic agricultural landscapes. Journal of Ecology 99, $1152-1161$

Jamoneau, A., Chabrerie, O., Closset-Kopp, D., Decocq, G., 2012. Fragmentation alters beta-diversity patterns of habitat specialists within forest metacommunities. Ecography, 124-133.

Jones, H.E., Madeira, M., Herraez, L., Dighton, J., Fabiâo, A., González-Rio, F., Fernandez Marcos, M., Gomez, C., Tomé, M., Feith, H., Magalhâes, M.C., Howson, G., 1999. The effect of organic-matter management on the productivity of Eucalyptus globulus stands in Spain and Portugal: tree growth and harvest residue decomposition in relation to site and treatment. Forest Ecology and Management 122, 73-86.

Kiviniemi, K., Eriksson, O., 2002. Size-related deterioration of semi-natural grassland fragments in Sweden. Diversity and Distributions 8, 21-29.

Kolb, A., Dieckmann, M., 2004. Effects of environment, habitat configuration and forest continuity on the distribution of forest plant species. Journal of Vegetation Science 15, 199-208.

Laughlin, D.C., Fulé, P.Z., Huffman, D.W., Crouse, J., Laliberté, E., 2011. Climatic constraints on trait-based forest assembly. Journal of Ecology 99, 14891499.

Lawesson, J.E., de Blust, G., Grashof, C., Firbank, L., Honnay, O., Hermy, M., Hobitz, P., Jensen, L.M., 1998. Species diversity and area-relationships in Danish beech forests. Forest Ecology and Management 106, 235-245.
Lomba, A., Bunce, R.G.H., Jongman, R.H.G., Moreira, F., Honrado, J., 2010. Interactions between abiotic filters, landscape structure and species traits as determinants of dairy farmland plant diversity. Landscape and Urban Planning 99, 248-258.

Lomba, A., Vicente, J., Moreira, F., Honrado, J., 2011. Effects of multiple factors on plant diversity of forest fragments in intensive farmland of Northern Portugal. Forest Ecology and Management 262, 2219-2228.

Lomolino, M.V., 2000. Ecology's most general, yet protean pattern: the species-area relationship. Journal of Biogeography 27, 17-26.

Magura, T., Báldi, A., Horváth, R., 2008. Breakdown of the species-area relationship in exotic but not in native forest patches. Acta Oecologica 33, 272-279.

Mendes, A.C., 2007. Uma história de ascensão e queda. In: Sande Silva, J. (Ed.), Árvores e Florestas de Portugal, Pinhais e Eucaliptais - A floresta cultivada. Público, Comunicação Social, SA AND Fundação Luso-Americana para o Desenvolvimento, Lisboa, p. 283.

Morgan, J., Wong, N., Cutler, S., 2011. Life-form species-area relationships in a temperate eucalypt woodland community. Vegetatio 212, 1047-1055.

Økland, R., Bratli, H., Dramstad, W., Edvardsen, A., Engan, G., Fjellstad, W., Heegaard, E., Pedersen, O., Solstad, H., 2006. Scale-dependent importance of environment, land use and landscape structure for species richness and composition of SE Norwegian modern agricultural landscapes. Landscape Ecology 21, 969-987.

Pereira, H.M., Daily, G.C., 2006. Modeling biodiversity dynamics in countryside landscapes. Ecology 87, 1877-1885.

Petit, S., Griffiths, L., Smart, S.S., Smith, G.M., Stuart, R.C., Wright, S.M., 2004. Effects of area and isolation of woodland patches on herbaceous plant species richness across Great Britain. Landscape Ecology 19, 463-471.

Proença, V., Pereira, H.M., Guilherme, J., Vicente, L., 2010. Plant and bird diversity in natural forests and in native and exotic plantations in NW Portugal. Acta Oecologica 36, 219-226.

Rodríguez-Loinaz, G., Amezaga, I., Onaindia, M., 2012. Does forest fragmentation affect the same way all growth-forms? Journal of Environmental Management $94,125-131$.

Sala, O.E., Chapin III, F.S., Armesto, J.J., Berlow, E., Bloomfield, J., Dirzo, R., HuberSanwald, E., Huenneke, L.F., Jackson, R.B., Kinzig, A., Leemans, R., Lodge, D.M. Mooney, H.A., Oesterheld, M., Poff, N.L., Sykes, M.T., Walker, B.H., Walker, M., Wall, D.H., 2000. Global biodiversity scenarios for the year 2100. Science 287, 1770-1774.

Saura, S., Cabral, J.A., 2004. Discrimination of native and exotic forest patterns through shape irregularity indices: an analysis in the landscapes of Galicia, Spain. Landscape Ecology 19, 647-662.

Tjørve, E., 2009. Shapes and functions of species-area curves (II): a review of new models and parameterizations. Journal of Biogeography 36, 1435-1445.

Tjørve, E., 2011. Arrhenius and gleason revisited: new hybrid models resolve an old controversy. Journal of Biogeography 39, 629-639.

Tjørve, E., 2012. Arrhenius and Gleason revisited: new hybrid models resolve an old controversy. Journal of Biogeography 39, 629-639.

Tjørve, E., Tjørve, K.M.C., 2008. The species-area relationship, self-similarity, and the true meaning of the $z$-value. Ecology 89, 3528-3533.

Trisorio, A., Povellato, A., Borlizzi, A., 2010. High Nature Value Farming Systems in Italy: a Policy Perspective", Paper Presented at the OECD Workshop on OECD Agri-Environmental Indicators: Lessons Learned and Future Directions, 23-26 March, 2010, Leysin, Switzerland.

Turner, W.R., Tjørve, E., 2005. Scale-dependence in species-area relationships. Ecography 28, 721-730.

van Halder, I., Barbaro, L., Corcket, E., Jactel, H., 2008. Importance of semi-natural habitats for the conservation of butterfly communities in landscapes dominated by pine plantations. Biodiversity and Conservation 17, 1149-1169.

Vicente, J., Alves, P., Randin, C., Guisan, A., Honrado, J., 2010. What drives invasibility? A multi-model inference test and spatial modelling of alien plant species richness patterns in northern Portugal. Ecography 33, 1081-1092.

Wang, X., Wiegand, T., Wolf, A., Howe, R., Davies, S.J., Hao, Z., 2011. Spatial patterns of tree species richness in two temperate forests. Journal of Ecology 99, 13821393.

Yamaura, Y., Kawahara, T., Iida, S., Ozaki, K., 2008. Relative importance of the area and shape of patches to the diversity of multiple Taxa. Conservation Biology 22, 1513-1522.

Żmihorski, M., Chylarecki, P., Rejt, Ł., Mazgajski, T., 2010. The effects of forest patch size and ownership structure on tree stand characteristics in a highly deforested landscape of central Poland. European Journal of Forest Research 129, 393-400.

Zschokke, S., Dolt, C., Rusterholz, H.-P., Oggier, P., Braschler, B., Thommen, G.H., Lüdin, E., Erhardt, A., Baur, B., 2000. Short-term responses of plants and invertebrates to experimental small-scale grassland fragmentation. Oecologia 125, 559-572. 